\title{
Microbiological Quality of Lactuca sativa (Lettuce) Salad Vegetables Sold in Restaurants in Kigali, Rwanda
}

Claudine Umuhire

\section{Pathology Department, University Teaching Hospital of Kigali}

Correspondence to: Claudine Umuhire, University Teaching Hospital of Kigali, KN 4,Avenue Kigali- Rwanda; E-mail: umuhirecloe@gmail.com

\begin{abstract}
Background

Salad which is served at restaurants in uncooked form can be source of bacterial contamination. Aim

To assess the microbiological quality of lettuce (Lactuca sativa) salads sold in two restaurants in Kigali, Rwanda.

Methods

Lettuce samples were collected using aseptic techniques and immediately analysed using standard media for E. coli, Salmonella, Shigella and Staphyloccocus aureus besides total aerobic count.

Results

The number of total aerobic bacteria ranged from $1.15 \times 10^{4}$ to $2.87 \times 10^{4} \mathrm{cfu} / \mathrm{ml}$ for restaurant 1 and from $1.91 \times 10^{4}$ to $2.13 \times 10^{5} \mathrm{cfu} / \mathrm{ml}$ for restaurant 2. Staphyloccoci count ranged from $3.6 \times 10^{2}$ to $1.173 \times 10^{3} \mathrm{cfu} / \mathrm{ml}$ for restaurant 1 and from $1.9 \times 10^{2}$ to $3.2 \times 10^{2} \mathrm{cfu} / \mathrm{ml}$ for restaurant 2 . Gram negative bacteria count ranged from $8.3 \times 10^{2}$ to $1.03 \times 10^{5} \mathrm{cfu} / \mathrm{ml}$ for restaurant 1 and from 5.05 $\mathrm{x} 10^{2}$ to $2.30 \times 10^{5} \mathrm{cfu} / \mathrm{ml}$ for restaurant 2. Salmonella and Shigella count ranged from $2.54 \times 10^{3}$ to $2.04 \times 10^{4} \mathrm{cfu} / \mathrm{ml}$ for restaurant 1 and from $3.65 \times 10^{3}$ to $2.5 \times 10^{4} \mathrm{cfu} / \mathrm{ml}$ for restaurant 2 . E. coli was found in $75 \%$ of the sample from restaurant 1 and $100 \%$ of the sample from restaurant 2 . Conclusion: Improvement in hygiene is needed during preparation and handling of lettuce salad in these restaurants.
\end{abstract}

Rwanda J Med Health Sci 2019;2(3):277-280

Key words: Lactuca sativa, microbiological quality, restaurants, Rwanda

\section{Background}

Salad vegetables are served as one of the buffet composition in Rwandan restaurants. They are generally eaten raw or partially cooked. They become source of foodborne illnesses if not cleaned properly. Vegetables can become contaminated while growing or during harvesting, postharvest handling, or distribution.[1,2] The most common bacterial enteropathogens associated with fruits and vegetables are enteric pathogens such as Escherichia coli [3-5] and Salmonella spp. [4,5] Staphylococcus aureus is also a potential pathogenic agent that can cause salad contamination. [6]

Epidemiological and laboratory evidence points to Salmonella enteritidis as the cause of gastroenteritis following the consumption of food at a school function. [7] An outbreak of Escherichia coli due to contaminated lettuce has been reported in the USA in 2011.[8] Contamination of ready-to-eat salads with Clostridium difficile was reported in Scotland.[9]

Vegetables are contaminated with microorganisms when they are irrigated with contaminated sewage water and when the soil is fertilized with contaminated manure [10]
Green salad leaves are attracting growing international concern as a potential source of foodborne pathogens, not only in domestic markets, but also in international trade. Vegetables such as lettuce and spinach are vulnerable to contamination at many stages in the food supply chain, but it is contamination in the field that is most worrying, mainly because the options for subsequent decontamination of green salad leaves are so limited.[11] The aim of this study was to assess microbiological quality of lettuce salad vegetables sold in two selected restaurants of Kigali City, Rwanda.

\section{Methods}

This study was conducted in Kigali City, Rwanda. Once a week samples of lettuce salad vegetables were collected from two most popular restaurants in town at lunch time. Samples consisted of ready-to-eat mixed salad taken in a sterile take away box. They were immediately transported to the microbiology laboratory of the College of Science and Technology, University of Rwanda, where microbiological analysis was done the same day. 


\section{Sample preparation}

Each sample provided $10 \mathrm{~g}$ of vegetable material, which was homogenized in $90 \mathrm{ml}$ of peptone water. This suspension was serially diluted in peptone water.

\section{Microbiological analysis \\ Isolation}

Gram negative bacteria were detected by culturing the sample on MacConkey culture media. Staphyloccocus aureus was isolated on Mannitol Salt Agar (MSA). Total aerobic bacteria were cultured on Nutrient agar media permitting the growth of gram positive and gram negative bacteria. Colonies were counted using a colony counter. Salmonella and Shigella were isolated on Salmonella shigela SS agar media.

\section{Identification of bacteria}

\section{Gram staining}

Some colonies were picked from culture media and spread on slide to make a smear which was dried, fixed and then colored using crystal violet for 1 minute, washed to remove it then alcohol was putted for 30 seconds and safranin for 1 minute which colors in red; then the slide was dried and observed under microscope using immersion oil. Gram positive bacteria were colored in violet/dark blue while gram positive bacteria were colored in red/pink.

\section{Biochemical tests}

After isolation of bacteria into nutrient agar, MacConkey agar, Mannitol Salt agar and Salmonella Shigella agar, pure colonies were picked and cultured on identification media. Simmons citrate was used to differentiate the Enterobacteriaceae. Catalase test was used for presumptive differentiation of streptococci (catalase negative), staphylococci (catalase positive), and listeria (catalase positive) from beta hemolytic streptococci. Coagulase test was used to differentiate Staphylococcus aureus from Staphylococcus epidermidis as well as streptococcus organisms. Coagulation within 24 hours was indicative of Staphylococcus aureus. The triple sugar iron test was performed on a pure culture of the organism obtained from the isolation media and inoculated in the tubes and then incubatedd at $35^{\circ} \mathrm{C}$ for $18-24$ hours, after what tubes were read for acid production of slant/butt, gas, and hydrogen sulfide reactions. Methyl red test was performed on pure colonies from different Petri dishes: MacConkey, SS agar, nutrient agar and mannitol salt agar were picked and inoculated into MR-VP medium and incubated at $37^{\circ} \mathrm{C}$ for $24 \mathrm{~h}$, then drops of methyl red solution were added to see the change of color. Urea test was performed on colonies from each kind of Petri dishes: nutrient agar, MacConkey, MSA, and SS agar were picked and inoculated into urea broth medium and incubated at $37^{\circ} \mathrm{C}$ for $24 \mathrm{~h}$. This test is done to determine a bacteria's ability to hydrolyze urea to make ammonia using the enzyme urease.

\section{Statistical analysis}

Analysis was made on Microsoft Excel software version 2007 to calculate the percentage of samples which were contaminated with bacteria in both restaurants.

\section{Results}

The counts for total aerobic bacteria, Staphyloccoci, gram negative bacteria and Salmonella shigella during the period of one month are shown in Table 1.

Table 1. Microbial quality of lettuce salad vegetables on different media during a period of one month

\begin{tabular}{llllll}
\hline Restaurant & Period & $\begin{array}{l}\text { Total aerobic } \\
\text { bacteria cfu/ml }\end{array}$ & $\begin{array}{l}\text { Staphyloccocus aureus } \\
\text { cfu/ml }\end{array}$ & $\begin{array}{l}\text { Gram } \\
\text { negative } \\
\text { bacteria } \\
\text { cfu/ml }\end{array}$ & $\begin{array}{l}\text { Salmonella Shigella } \\
\text { cfu/ml }\end{array}$ \\
\hline \multirow{6}{*}{ Restaurant 1 1} & Nutrient agar & MSA & $\begin{array}{l}\text { Mac Conkey } \\
\text { agar }\end{array}$ & $\begin{array}{l}\text { Salmonella Shigella } \\
\text { agar }\end{array}$ \\
& Week 2 & $2.87 \times 10^{4}$ & $3.6 \times 10^{2}$ & $1.03 \times 10^{5}$ & $2.04 \times 10^{4}$ \\
& Week 3 & $1.15 \times 10^{4}$ & $1.173 \times 10^{3}$ & $8.3 \times 10^{2}$ & $2.54 \times 10^{3}$ \\
& Week 4 & $2.46 \times 10^{4}$ & $4.85 \times 10^{2}$ & $1.59 \times 10^{3}$ & $1.73 \times 10^{4}$ \\
& Week 1 & $2.13 \times 10^{5}$ & $2.95 \times 10^{2}$ & $2.20 \times 10^{3}$ & $2.73 \times 10^{3}$ \\
Restaurant 2 & Week 2 & $2.84 \times 10^{3}$ & $1.9 \times 10^{2}$ & $2.30 \times 10^{5}$ & $2.5 \times 10^{4}$ \\
& Week 3 & $1.91 \times 10^{4}$ & $3.2 \times 10^{2}$ & $1,15 \times 10^{3}$ & $3.65 \times 10^{3}$ \\
& Week 4 & $2.20 \times 10^{4}$ & $2.45 \times 10^{2}$ & $1.03 \times 10^{4}$ & $1.18 \times 10^{4}$ \\
\hline
\end{tabular}




\section{Microbial quality of salads vegetables according to PHLS guidelines}

The microbial quality of salads was classified into satisfactory, acceptable, unsatisfactory and unacceptable category following the microbial count.

E. coli was found in the percentage of $75 \%$ for restaurant 1 and $100 \%$ for restaurant 2. Staphyloccocus aureus was found in the percentage of $100 \%$ for restaurant 1 and $75 \%$ for restaurant 2. Salmonella was found with the prevalence of $50 \%$ for restaurant 1 and the prevalence of $50 \%$ for restaurant 2. Shigella was found with the prevalence of 25 $\%$ for restaurant 1 and $25 \%$ for restaurant 2 .

According to PHLS guidelines salads from restaurant 1 and restaurant 2 were satisfactory for the criterion of aerobic colony count. For indicator organisms E. coli, three samples were unsatisfactory in both restaurants and one sample was unacceptable in both restaurants. For pathogens organisms: Staphyloccocus aureus was in an acceptable range for both restaurant 1 and 2 . For Salmonella criterion two samples of restaurant 1 were unacceptable and two were satisfactory for both restaurants. For Shigella criterion one sample was unacceptable for both restaurants and three samples were satisfactory.

\section{Discussion}

The results obtained in this study testify that minimally processed vegetable salads have potential contamination by foodborne pathogens. According to PHLS guidelines Staphyloccocus aureus was in an acceptable range for both restaurant 1 and 2 . Its presence may be an indication of human contact.

However the presence of Salmonella in two samples of lettuce salads and shigella in one sample for both restaurants shows that they can be an important vector for the transmission of pathogenic bacteria to consumers. The contamination level of lettuce, compared to other type of vegetable, is due to its small size which promotes the deposition of soil bacteria and manure under the effect of watering or other mechanisms.

The presence of E. coli in foods is an indicator of direct or indirect fecal contamination. It is also an indicator of the possible presence of enteric pathogens.

Presence of pathogenic agents on lettuce indicates that the wash procedure was inefficient either due to the inappropriate wash medium or wash time. $[12,13]$ Crosscontamination through food handling has also been reported when utensils are not sufficiently cleaned and are used for different types of foods.[14] However bacterial internalization in vegetable leaves has been reported for lettuce, which makes disinfection inefficient. $[11,15]$

\section{Conclusion}

Lettuce salad vegetables served in some restaurants of Kigali may harbour some pathogens which cause diseases. According to the results some samples were safe but others unsafe. It is advised to implement strategies which include an improvement in the preparation and handling of salads before and after their preparation.

\section{Recommendation}

The owner of restaurants should improve their hygiene during the preparation of their food by a proper cleaning of the materials, good wash of salads before preparing, and add some amount of vinegar.

Only two restaurants were investigated; further investigation is warranted to have a global situation on the food hygiene of Rwandan restaurants.

\section{Author's Contribution}

CU designed the study, collected the samples, carried out the laboratory tests and data analysis and wrote the manuscript.

\section{Acknowledgments}

The author is thankful to Professor Wilson Parawira and Professor Francis Nzabuheraheza, Department of Biotechnology, Faculty of Applied Sciences, INES Ruhengeri, for their scientific guidance and to Prof. Jean Bosco Gahutu, College of Medicine and Health Sciences, University of Rwanda, for reviewing the manuscript.

\section{Disclosure statement}

There is no financial conflict of interest.

This article is published open access under the Creative Commons Attribution-NonCommercial NoDerivatives (CC BY-NC-ND4.0). People can copy and redistribute the article only for noncommercial purposes and as long as they give appropriate credit to the authors. They cannot distribute any modified material obtained by remixing, transforming or building upon this article. See https://creativecommons.org/ licenses/by-nc-nd/4.0/ 


\section{References}

1. Abadias M, Usall J, Anguera M, Solsona C, Viñas I. Microbiological quality of fresh, minimallyprocessed fruit and vegetables, and sprouts from retail establishments. Int J Food Microbiol. 2008;123:121-129.

2. Korir RC, Parveen S, Hashem F, Bowers J. Microbiological quality of fresh produce obtained from retail stores on the Eastern Shore of Maryland, United States of America. Food Microbiol. 2016;56:29-34. doi: 10.1016/j. fm.2015.12.003

3. Oliveira M, Usall J, Viñas I, Anguera M, Gatius F, Abadias M. Microbiological quality of fresh lettuce from organic and conventional production. Food Microbiol. 2010;27:679-684

4. Leff JW, Fierer N. Bacterial Communities Associated with the Surfaces of Fresh Fruits and Vegetables. PLoS One. 2013;8(3): e59310. doi:10.1371/ journal.pone. 0059310.

5. Hou Z, Fink RC, Radtke C, Sadowsky MJ, DiezGonzalez F. Incidence of naturally internalized bacteria in lettuce leaves. Int J Food Microbiol. 2013;162:260-265.

6. Le Loir Y, Baron F, Gautier M, Le Loir Y. Staphylococcus aureus and food poisoning. Genet Mol Res. 2003;2(1):63-76.

7. Niehaus AJ, Apalata T, Coovadia YM, Smith AM, Moodley P. An Outbreak of Foodborne Salmonellosis in Rural KwaZulu-Natal, South Africa. Foodborne Pathog Dis. 2011;8(6):693-697. DOI: $10.1089=$ fpd.2010.0749.

8. Slayton RB, Turabelidze G, Bennett SD, Schwensohn CA, Yaffee AQ, Khan F, et al. Outbreak of Shiga Toxin-Producing Escherichia coli (STEC) O157:H7 Associated with Romaine Lettuce Consumption, 2011. PLoS One. 2013;8(2): e55300. doi:10.1371/journal.pone.0055300
9. Bakri MM, Brown DJ, Butcher JP, Sutherland AD. Clostridium difficile in ready-to-eat salads, Scotland. Emerg Infect Dis. 2009;15(5):817-818

10. Oliveira M, Viñas I, Usall J, Anguera M, Abadias M. Presence and survival of Escherichia coli O157:H7 on lettuce leaves and in soil treated with contaminated compost and irrigation water. Int J Food Microbiol. 2012;156:133-140.

11. Golberg D, Kroupitski Y, Belausov E, Pinto R, Sela S. Salmonella Typhimurium internalization is variable in leafy vegetables and fresh herbs. Int J Food Microbiol. 2011;145:250-257.

12. Tomás-Callejas A, López-Velasco G, Camacho AB, Artés F, Artés-Hernández F, Suslow T V. Survival and distribution of Escherichia coli on diverse fresh-cut baby leafy greens under preharvest through postharvest conditions. Int J Food Microbiol. 2011; 151:216-222.

13. Munther D, Wu J. Enhanced surveillance on food-borne disease outbreaks: Dynamics of cross-contamination in biocidal wash procedure. J Theor Biol. 2013; 321:28-35.

14. Ravishankar S, Zhu L, Jaroni D. Assessing the cross contamination and transfer rates of Salmonella enterica from chicken to lettuce under different food-handling scenarios. Food Microbiol. 2010;27:791-794.

15. Kroupitski Y, Pinto R, Belausov E, Sela S. Distribution of Salmonella typhimurium in romaine lettuce leaves. Food Microbiol. 2011;28:990-997. 